Geological Society of America

Memoir 145

(C) 1976

\title{
Oxygen-Isotope and \\ Paleomagnetic Stratigraphy of \\ Pacific Core V28-239 \\ Late Pliocene to Latest Pleistocene
}

\author{
N.J. SHA.KLETON \\ Sub-deparntent of Qtuternary Research \\ University of Cambridge. \\ 5 Salisbur: Vilias, Station Road \\ Cambriage. Engiand CB1 2JF \\ AND \\ N. D. OPDYKe \\ Lamont-Doherty Geological Observa:ery \\ Coiumbia University \\ Palisades, New Yorh 10sost \\ and \\ Department of Geologicat Sciences \\ Columbia L'niversity \\ New York, New York 10027
}

\begin{abstract}
V28-239 core from cruis: 28 of R/V Vema preserves a detailed oxygen-isotope and paleomagnetic record for all of the Pleistccene Epoch. The entire $2 \mathrm{i}$-m-iong core has been analyzed at 5-cm intervals. Glacial stage 22, above tie Jaramillo magnetic event, inay represent the first major Northern Hemisphere continental glaciation of middle Pleistocene character. Prior to this, higher frequency giacial events extend to near the leve! of the Olduvai magnetic e rent. Glacial events of less regular frequency extend to the bottom of the core, which represents late Pliocene time. Fuctustions in zartonate dissolution intensity occur throughout the cure with a similar frequency to the oxygen-isotope fluctuations.
\end{abstract}




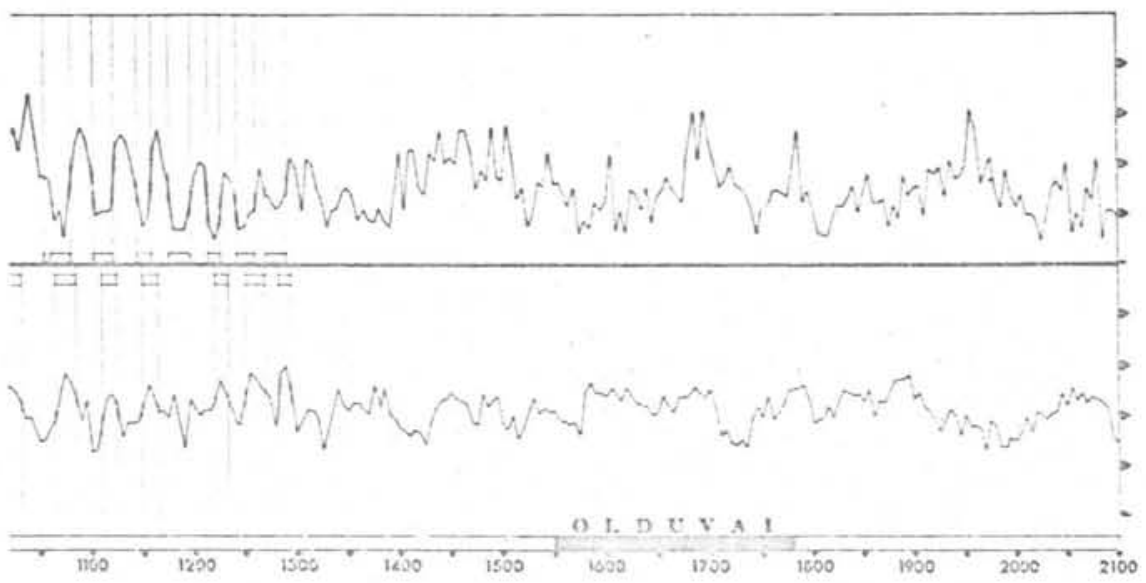

Ways and othars (1S69); stags in the oxgen-fsotoye recurd are numbered after Emititui (IS55. $19 S 5)$ and Sinstition and Optyice (1973).

Sedimen: samcles ware disaggregated in distilfed water: foraninifers were selected for analysis from the $>182-\mu m$ fracton after sieving and ultrasonic cleating. Sample pretreatment and chemical piocessing were identieal to thove used for core V28-238 (Sharcileton enil Opdylic. 1973). Isutupe analysis was performed in a new V.G. Micromass $602 C$ mass spectrometer. Aralyses are referred to the PDB standard

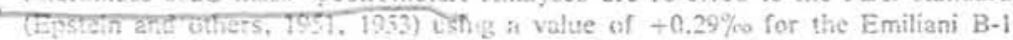
stanciard (Stiacliteton, 1974). This zeltiration is : ccurate in better than $=0.05 \%$. Analytical restits in Shacideton and Opdyke (1973) wete referred to the B-1 standard and must be corrected by $+0.29 \%$ before comparison with the data presented in this paper

A. single aralysis has been made at each level in the core. For each analysis. 15 specimens of Globigerinoides sacrulije were selected in the lower part of the core $G$. fistulosus was used in some samples, three samples contrined insufficient apecimens for analysis, and a few cuntained less than 15). Analytical precision is estimated to be $+0.05 \%$, the standard deviation for 105 analyses of a sturidard carbonate performed during the first six months of instrument operation. However. the uncertainty in analysis of a single sample from the sediment is $\pm 0.11 \%$ (Shackleton and Opdyke, 1973). Isotopic variability among the specimens and analytical precision are combined in this iigure. Anaiytical results arc given in Table 1. Figure 1 shows the percentage ty weight retained on the 180 - $1 \mathrm{~m}$ sieve for each sample, the oxygen-isotope record, and the paleomagnetic reord.

\section{Character of the isotopic Record}

Jaramillo Magnetic Event to Present. Figure 1 suggests that the oxygen-isutope record may he divided into three eptsodes of differing character The upper part. all of which is represented in core V28-238 (Fig. 2) as well as core V28-239. contains glacial stages ai approximately $100,000-y r$ intervais. Apparently, the isotopic composition of the ectan changed by almost the same extent in every glaciation 
during this interval. The rather large variability among glacial extreme isotopic values in core V28-239 is an artifact of sedimertation processes. This is evident from the fact that the extreme isotopic values in successive glaciations are both less variable and more distant from the Holocene value in cores with higher eccumulation rates. In core V28-239 $\left(1.0 \mathrm{~cm} / 10^{3} \mathrm{yi}\right)$ the extreme isotopic values in glacial steges 2 and 6 to 22 differ from the Holocene vaiue by $1.22=0.24 \%$. In core V28-238 $\left(1.7 \mathrm{~cm} / 10^{3} \mathrm{yr}\right)$ the same ten glacial extreme values differ from the Holocene value by $1.04 \pm 0.14 \% \mathrm{~m}$. In core $V 19.28\left(4.0 \mathrm{~cm} / 10^{3} \mathrm{yr}\right)$ the last five glacial extreme values differ from the Holocene value by $1.62=0.11 \%$. (Ninilovich and Shackleton, 1975).

Figure I shows cyclic chaniges in the percentage of sediment that is greater than $180 \mu m$ as well as in oxygen-isotope composition. Thompson and Saito (1974) cocumented correlative cyclic variations in dissolution intensity in cores V28-238. V26-239, and RCt1-210. The latter care is in the region where Hays and others (1959) defincd dissolution zones on the basis of changing carbonate percentage. Thus, we may confidently ascribe the observed variations in coarse-fraction percentige to changes in dissolution intensity and assiga them to zones according to the definition of Fays and others (1957). Figure ! shows these dissolution zones. The delay between the climatic change recorded in the oxygen-isotope record and the dissolution change, noted by Luz and Shackleton (1975) and by Ninkovich and Shackiteton (1975), is preserved throushout the sequence.

Characteristictily, the transition from gitcial to interglacial axtreme occtrrad very rapidly (Eroecker and van Donk. 1970): inseed. 12.000 yr sgo deplacintion took place so fast that its record in sediment cores is almost invariably determined by the sediment-mixing depth rather than by the actual rate of change in the isotopis eortiposition of thie ocein (at lesct $0.3^{\prime \prime} y^{\prime} 10^{3} \mathrm{yt}$ ). Glaciat stages 2.6 . $10,12,20$. and 22 terminaied in this memer. Stages 4. 8, and 14 probably did

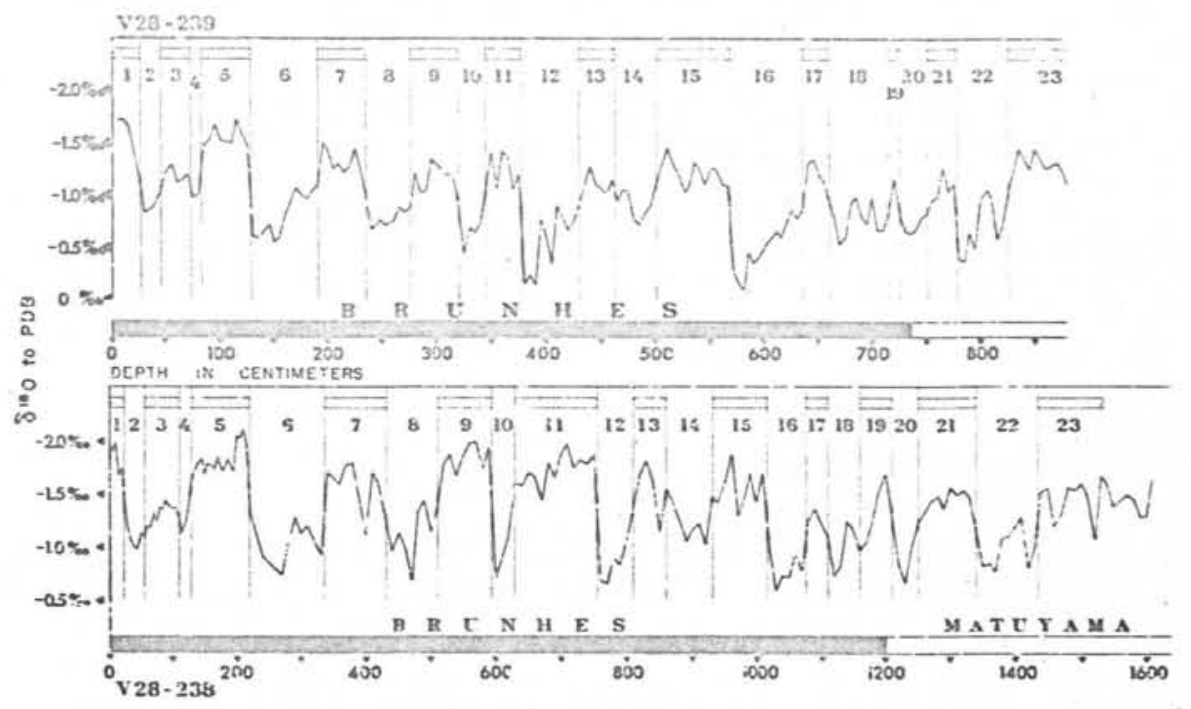

Figure 2. Oxygen-isotope and paleomagnetic record in upper $880 \mathrm{~cm}$ of cores V25-239 (above) and V28-238 (beiow ). 
V16-205 seems to contain even greater changes in accumulation rate than V28-239. The rate between the Jaramillo and the top of the Brunhes in core V16-205 is reported to be $0.25 \mathrm{~cm} / 10^{3} \mathrm{yr}$. although the average rate through the entire core is $0.55 \mathrm{~cm} / 10^{3} \mathrm{yr}$. It is to be hoped that interoceanic correlations for the Matuyama epoch will become more reliable with the analysis of more cores in both the oceans.

\section{ISOTOPE STRATIGRAPHY AND TTS LINITATIONS}

\section{Oxygen-Isotoge Strses: Terminology}

Emiliani (1955. 1955) used numbers I to 16 to designate stages that he recognized in oxygen-isotope records he obtiined in sediment cores from the Caribbean Sea and Atlantic Ocean. We (Shaclteton and Opdyle. i973) recognized 22 stages in core V28-238, the firs! 16 coinciding with those used by Emiliani. As a step toward formalizing this nomenelature. stage botndaries were detined by the depth at which they were loceted in core V28-238 (Fig. 2). For ccre V2s.239. 23 stages are shown in Figure 1 ; the depths of stage houndaries. placed by correiation with core V28-238. are given in Table 2.

Before considering the extention of this termirology. it is important to cunsider th: assuniptions on which use of the oxygen-isotope record as a stratigraphic trol is based and the imitations of its usefulness. It is universally agreed that at the
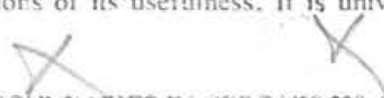

TABLE 2 STAGE BOLNDARIES IN CORE V?R-239 AS DETFRMINED BV

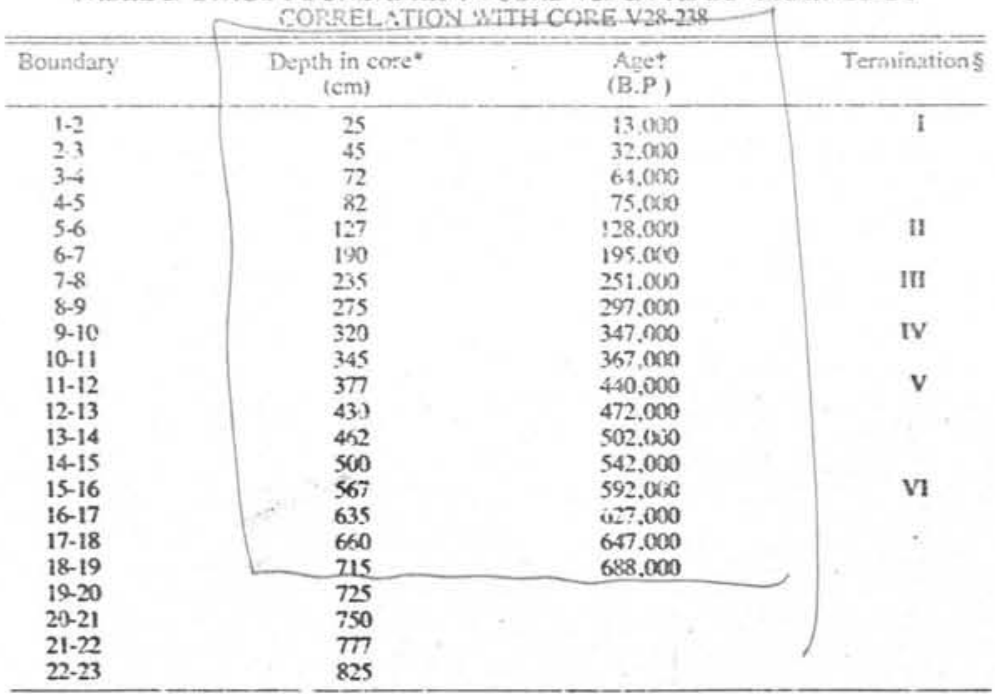

- Determined by correlation with core V28-238.

+Ases are those estimated by Shackleton and Opdyke (1973) by linea merolation in core V $28-238$ wing a raie of $1.7 \mathrm{~cm} / !^{3} \mathrm{yr}$.

$\S$ Terminations from Broecker and van Junk (1969). They affuned terminations on the basis of their interpretation of the saw-toxthed character of the oxygen-isotope recurd. Owing to a pussible biatus in core V12-122, it appears that the evert laceled terrvinatioc ill by them is the stage $16-15$ boundary. 
depth (Berger and Heath. 1968; Ruddinian and Glover, 1972), and the extremes analyzed must therefore approximate the extremes present in the core. The mean amplitude of isotopic fluctuations is less in core V28-239 than in V28-238, probably because the accumulation rate is lower in comparison with the mixing depth.

We have argued that the observed peak-to-peak amplitude of oxygen-isotope changes in core V2⿺-238 was reduced by mixing (Shackleton and Opdyke, 1973). Thus, the full range of isotopic variation is attenuated in the sediment in core V28-233 and even more so in core V23-239. However, both cores preserve sufficient record that successive stages can be unambiguously recognized.

\section{Carborate Dissolution and the Orygen-Isotope Record}

Core V23-239 was taken at a depth of $3.490 \mathrm{~m}$, compared to $3.120 \mathrm{~m}$ for core V23-233. This accounts for more intense dissolution occurring in core V28-239. Savin and Dovgles (1973) pointed out that increasing dissolution not only procres. sively removes the more solution-susceptibte species (often those that lived in shallower water, but it also selectively removes from the population of a single species thos members that lived closer to the surface. Thus, the fossil population that has suffered more dissolution registers a lower isotopic temperature as a consequence of that dissolution.

TABLE 3. STAGE-BY-STAGE ISOTOPE EXTREMES FOR CORES V28-239 AND V2S-238

\begin{tabular}{|c|c|c|c|c|c|c|}
\hline \multirow[t]{2}{*}{ Stage } & \multirow[t]{2}{*}{ Interval } & \multicolumn{2}{|c|}{$v_{2}-239$} & \multicolumn{2}{|c|}{$v 2 \mathrm{i}-238$} & \multirow{2}{*}{$\begin{array}{l}\text { Berulen core } \\
\text { Difference } \\
(\mathrm{A}-\mathrm{C})^{*} \\
\end{array}$} \\
\hline & & $\begin{array}{c}A \\
\text { (8). } \\
\%\end{array}$ & $\begin{array}{c}\text { B } \\
\text { itange; }\end{array}$ & (5. $\left.{ }^{C}{ }_{\infty}{ }^{\infty}\right)$ & $\begin{array}{c}D \\
\text { (range) }\end{array}$ & \\
\hline 1 & 1.2 & -1.72 & 0.83 & -1.93 & 1.01 & 0.26 \\
\hline 2 & $2-3$ & -0.84 & 0.85 & -0.97 & $\begin{array}{l}1.01 \\
0.47\end{array}$ & 0.13 \\
\hline 3. & $3-4$ & -1.30 & 0.32 & -1.44 & 0.59 & 0.14 \\
\hline 4 & 45 & -6.93 & 0.74 & -0.85 & 1.26 & -0.13 \\
\hline 5 & $5-5$ & -1.72 & 116 & $-2.11 !$ & 1.37 & 0.39 \\
\hline 6 & $6-7$ & -0.55 & 0.94 & -0.74 & 1.05 & 0.18 \\
\hline 7 & 7.8 & -1.50 & 0.82 & -1.79 & 1.10 & 0.29 \\
\hline 8 & $8-9$ & $-0.6^{2}$ & 0.67 & -6.69 & 1.30 & 0.01 \\
\hline 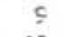 & $2-10$ & $-i .35$ & 0.90 & -1.99 & 1.28 & 0.64 \\
\hline 10 & $10-11$ & -0.45 & 0.97 & -0.71 & 1.26 & $0.2 b$ \\
\hline 11 & $11-12$ & $-i .42$ & 1.28 & -1.97 & 1.32 & 0.55 \\
\hline 12 & $12-13$ & -0.14 & 1.14 & -0.65 & 116 & 0.51 \\
\hline 13 & 13.14 & -1.28 & 0.56 & -1.81 & 0.76 & 0.53 \\
\hline 14 & 14 is & -0.72 & 0.73 & -1.05 & 0.82 & 0.33 \\
\hline 15 & $15-16$ & -1.45 & 1.35 & -1.87 & 1.28 & 0.42 \\
\hline 16 & $16-17$ & -0.10 & i. .25 & $-0.5 \circ$ & 0.77 & 0.49 \\
\hline 17 & $1 ;-18$ & -1.35 & 0.82 & -1.36 & 0.64 & $0.0 \mathrm{i}$ \\
\hline 18 & $18-19$ & -0.53 & 0.63 & -072 & 0.97 & 0.19 \\
\hline 19 & $19-20$ & -1.16 & $0.5 ?$ & -1.69 & 1.03 & 0.53 \\
\hline 20 & $20-21$ & -9.64 & 0.63 & -0.65 & 0.87 & 0.02 \\
\hline 21 & $23-22$ & -1.27 & 0.90 & -1.53 & 0.86 & 0.26 \\
\hline 22 & & -0.37 & 0.30 & -0.7 & & 0.40 \\
\hline
\end{tabular}

Note: Colum A, extreme oxygen-sotopic compssition in each stage in core V28-239, from Table 1. Column B, tsotopic difference betwe en actiacent stages in core V $38-239$. Mean n $84 \pm 0.28$. Column C, exireme oxyren-isotopic composition in each stage in core V2z-238. from Shackletos and Opdyke (1973, Table 1), corrected to PL'B standard. Cclumn D, isotopic difference betwien adjacent stages in core V24-238. Mean $1.00=0.27$

- Difference hetween the ext:erna reached in cores V28-239 and V28-238 for each stage. Mean $6.29 \pm 0.21$. 
TABLE 4. THICKNESS OF CLIMATIC CYCLES IN A SUITE OF CARIBBEAN CORES AND IN PACIFIC CORES V28-238 AND V28-239

\begin{tabular}{|c|c|c|c|c|c|c|c|}
\hline \multirow{2}{*}{ stages } & \multicolumn{7}{|c|}{ Cores } \\
\hline & P6304-4 & P6304-7 & P5304-8 & P53049 & $\begin{array}{l}\text { Mean P6304 } \\
\text { suite }\end{array}$ & V $28-238$ & V28-239 \\
\hline 1 & 25 & 30 & 30 & 30 & 29 & 22 & 25 \\
\hline $2-3$ & 130 & 145 & 150 & 165 & 148 & 88 & 47 \\
\hline $4-5$ & 175 & 185 & 170 & 145 & 169 & 110 & 53 \\
\hline $6-7$ & 240 & 275 & 280 & 240 & 259 & 210 & 110 \\
\hline $8-9$ & 160 & 195 & 210 & 200 & 191 & 165 & 85 \\
\hline $10-11$ & 145 & 180 & 190 & 180 & 174 & 160 & 57 \\
\hline $12-13$ & 155 & 150 & $\therefore$ & 130 & 144 & 105 & 85 \\
\hline $14-15$ & 85 & $80 ?$ & . & 200 & $200^{*}$ & 155 & 105 \\
\hline $16-17$ & & & & & & 95 & 93 \\
\hline
\end{tabular}

Notc: Data for Caribsean cores from Entiliani (1955, 1972): for Pacific cores from Snactiteton and O-dyke (1973); for core V2H-239 from this paper.

"Deta for stsnes $14-15$ from F6304 suite is inconsistent. Value for 63049 has been adopted. bectuse it is mure consictent whit the Pacific cores (Figs. 3. 4).

performed on the basis of an assumed uniform sccumulation rate may be in error even if the extrapclation is bused on average accumulation rates from numerous cores.

\section{E.fect of Varying Suriace Temperature}

In the Caribbean. Emiitzni (1965) has shown that the oxygen-isotope conipusition of $G$. saccilifer in rezent sediment impites deposition at or near surface temperature. Vincent and Shackleten (1975; Rave shown that this is also trie in the India: Ocean. White this situation hold ; changes in surface temperature during Pieistocene time, if present. shut?d offect the ifotopic compostion of $G$. sacculifer populations in Pieistocene sedimant. Hence. $i$, is geticrally assumied that changes in sufface temperature may be estimated by subiacting the component that is ascriled to glacivlly induced changes in ocean istopic composition from the total record of oxygen-isotopic change (Imbric and others. 1973).

In the Pacific a different siluation prevalls: The oxygen-isotope composition of $G$. saccullifer corresponds to a termerature several degrees below sea-surface temperature in many cora-top semples (Stavin and Douglas. 1973). To wnat exient this fizure is an indicaticn of a difference in the depth distribution of caicification in the species and to what extent it is a function of selective dissolution of the individuals from sheilower depths in the water coltumn (Savin and Douglas. 1973) remain to be evaluated. However. we 'Shackleton and Opdyke. 1973) argued that the close similarity between the iso:opic recorcis of $G$. sacculifer and benthiz species in core V28-238 implies that botl: records depict the history of the isotopic composition of the ocean, and that changes in surface temperature. temperature-depth structure. Gepth distribution of $G$. succulijer, ard selective dissolution all play minor roles. Discrepancies between the plankionic and henthic recurds in core $v 28-238$ were ascribed by us (Shackleton and Opdyke. 1973) to the effects of postdepositional sediment mixing by burrowing crgarisms rather than to the factors mentioned above.

\section{Long-Term Trends in the Oxygen-Isotope Record}

There is no generat agreenent regarding any long-term trends in climate during Pleistocenc time; trends that emerge from studies hased on the present-day ecuiugical 
the climatic record. The intensity of dissolution rose not at the boundary between stages 6 and 5 (termination 11 of Bruecker and van Donk. 1970) but a few thousand years later. We now show that this relationship has held through the past 1.5 m.y.

Figure 1 indicates the boundaries of the dissolution zones, numbered according to the scheme of Hays and others (1959), and their relation to the oxygen-isotope stages. The dissolution zones are not manifested as carbonate fluctuations. and the carbonate content is high throughout the core (Thompson. 1976). However. Thompson and Stito (1974) have shown that change in dissolution intensity is the dominant factor in determining ti:e downcore changes in foraminiferal faunal composition in this area.

Figure I clearly indicates that Hays and others (1959) were correct in their assertion that chunges in carbonate content in eastern equatorial Pacific sediments could be correlated with the Northern Hemisphere climatic record and with oxygen-isotope records from the Caribbean. However. tuse of carbonate cycles as a precise stratigraphic tool may be misleading. Ficure I shows that the base of each dissolution zone in the sediment is not found at the same position as the glacial-to-interglacial isotopic transition, but rather some 5 to $20 \mathrm{~cm}$ above. This represents a delay of a few thousand years between the climatic change and its effect on bottom-water chemistry in the equatoral Pacific. This delay may not be constant from one latitude to unother or from one climatic cycle to another.

\section{CHRONOLOGY}

The rccord of changes in the oxygets-isotope composition of the woric uceans may be readily uscd as a stretisraphic toot in Pleistocere deep-sea sediments of all oceans the Atluntic and Cartobean. Emiliari. 1955: the Arctic, van Donk and Mathieu. 1969: the indian Oceen. Oba. 1959; the Pacific Ocean. Shacketon and Opdyte, 1973: the sub-Antarct $=\mathrm{r}$ gions. Hays and others, this volumel. Moreover. since the primary mechanism givi ig rise to these changes is the growth and retreat of continental ice sheets in the Nortivern Hemisphese. the record is of considerabie

Figure 5. Comparison of thichness of climatic cycles (odd- and succeeding even-numiered steges: in core V2\%-233 and in suite of cores P6304-4, P6304-7. P6304-8, and P5344-9 from Emilland (1958, 1972). Data from Table 4.

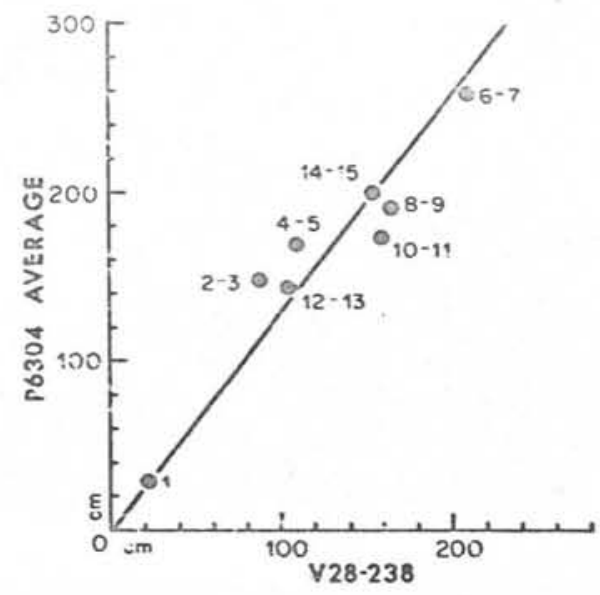




\section{REFERENCES CITED}

Arrhenius, G.. 1952, Sediment cores from the East Pacific: Swedish Deep-Sea Exped. Repts.. v. 5, p. 6-227.

Berger, W. H., and Heath. G. R., 1968, Vertical mixing in pelagic sediments: Jour. Marine Research. v. 26. p. 135-143.

Broecker. W. S., and van Donk. J.. 1970. Insolation changes, ice volumes and the $\mathrm{O}^{\text {"N }}$ record in deep-sea sediments: Rev. Geophysies and Sinece Physics, v. 8.. p. 169-198.

Dansgard. IV., and Tauber, H. 1959. Glacier oxygen-18 content and Rieistocene ocean temperatures: Science, v. 165, p. 499-502.

Emiliani, C.. 1955, Pleistocene tem peratures: Jour. Geology, v. 63. p. 533-578.

- 1955. Pelheotemperature analysis of Caribtean cores P5304-8 and P5304-9 and a gencralized temperature curve for the past f25.06 years: Jour. Geology, v. 74. p. 109-126.

- 1972 . Quaternary pu'eotempstalures and the duration: of the high-temperature intervai: Science, v. 178 , p. 398-40!.

Emilisri, C.. and Shacldeton. N. J.. 1974. The Brunhes epoch: Palaeotemperatures and Ecochronotomy: Science, v. 183. p. 5!1-514.

Epstein. S.. Ruchsbatim. R., Lowenstam. H.A., and Urey, it C. :951. Carbonate-water isotopic icmperature seale: Geol. Sx. America Bult., v. 62, p. 417-426.

- 1953, Revised carbonate-water isctopie temperature seaje: Geol. Soc. America Bull. v. 64 . P. $1315-i 326$.

Gordan. A. L.. 975. General ucean circulation. in Numerical models of ocean circulation: Washington. D.C.. Natl Acal. Sci.. p. 39-53.

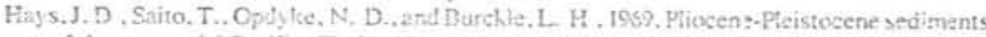

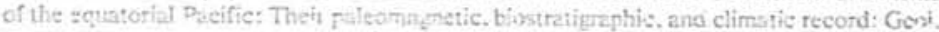
Soc. America Bub., v. Eo. p. $148:-1514$.

Hays, J. D. Lozam, J., Shatifetcn. N.. and Irving, G., 1976. Reconstruztion of the Atlantic Qcesn and vestern indian Oeean sectors of the 18.093 E.P. Antarctic Ocean, in Cline. R. M., tnd Hays, J. D., eds., Investigation of tate Quaternaty puleoceanogruphy and paleoclimatozy: Geo!. Soc, kutierica Wem. 145 (this volume).

Imbrie, J., van Donk, J., and Kips. N. G. IV73. Palesetimatic investigation of a Late Pleistocene fetp-seat core: Compurison of isetopic and faund methods: Quztetnary Research. v. z. p. $10-38$

Kernett. 3. P., and Strackletes, A. J., 1975. Latest Pleistocene melting of the Laurentide ice shett recorded in clezr-tea cores from the Gull of Mexico: Science, Y. 188. p. 147-1:0.

Kukla, J., 1970, Cortelations betueen lossses and decp-sea sediments: Geol. Fören. Stockiolm Forth., v. 92, p. 148-184

Luz. B., and Shackleton. N. J.. 1975 , CaCO, stution in the tropical Fast Pacific Juring the pas: 130,000 years: Custiman Found. Foran. Research Spec. Pub. 13 n. 142-150.

Ninkovich. D.. and Shackleton. N. J.. 1975, Distributicn. stratigraphic position and age of ash hyer "L." in the Pantina Basin rexion: Earth and Planetary Sci. Letters. v. 27. p. $20-3<$.

Wa. T., 1959. Biostratigraphy ano isotopic paleotemperatures of some deep-sea cores from the Indian Qtean: Toholu Univ. Sci. Rapts., 2nd set (Geology). * 41. p. 129-195.

Olausson. E., 1965. Evidence of slimatic changes in North A:tantic deep-sea cores, with remarks on isotopic palaeotenıperature anajysis- Prog. Ocearograpiny. v. 3. p. 221-252

Ruddiman. W. F., and Glover. L. K., 1972, vertical mixing of ice-rafted voleanic ash in North Atlantic sediments- Geol. Soc. Arrerica Bull., v. 83, p. 28!7-2836.

Savin. S. M.. and Douglas. R. G.. 1973, Stable isutope and magnesium geochernisin of recent planktonic Foraninifera from the South Facific: Geol. So:. America Bull.. v. 84. p. $2327-2342$.

Sha-kleton, N. J., 1967. Oxyen isotope analyses and paleoten.peratures re-assessed: Naiture. v. 215, p. $15-17$.

1974. Attainment of isotopic squalibriurr. betwe er ucean water and the benthonic forminifera genus Uvigerina: isotopic changes in the ocear thring the tast glacia': Paris. Centre National oe la Recherche Scientifique. Colloquium 219. 